\title{
Autoimmune Thyroiditis and Myasthenia Gravis
}

\author{
Angela Lopomo ${ }^{1}$ and Sonia Berrih-Aknin ${ }^{2,3,4 *}$ \\ ${ }^{1}$ Department of Translational Research and New Technologies in Medicine and Surgery, Division of Medical Genetics, \\ University of Pisa, Pisa, Italy, ${ }^{2}$ Sorbonne Universités, UPMC Univ Paris 06, Paris, France, ${ }^{3}$ INSERM U974, Paris, France, \\ ${ }^{4} \mathrm{AIM}$, Institute of Myology, Paris, France
}

Autoimmune diseases (AIDs) are the result of specific immune responses directed against structures of the self. In normal conditions, the molecules recognized as "self" are tolerated by immune system, but when the self-tolerance is lost, the immune system could react against molecules from the body, causing the loss of self-tolerance, and subsequently the onset of AID that differs for organ target and etiology. Autoimmune thyroid disease (ATD) is caused by the development of autoimmunity against thyroid antigens and comprises Hashimoto's thyroiditis and Graves disease. They are frequently associated with other organ or non-organ specific AIDs, such as myasthenia gravis (MG). In fact, ATD seems to be the most associated pathology to MG. The etiology of both diseases is multifactorial and it is due to genetic and environmental factors, and each of them has specific characteristics. The two pathologies show many commonalities, such as the organ-specificity with a clear pathogenic effect of antibodies, the pathological

OPEN ACCESS

Edited by:

Salvatore Benvenga,

University of Messina, Italy

Reviewed by:

Marco Centanni,

Sapienza Università di Roma, Italy

Carmelo Rodolico,

University of Messina, Italy

${ }^{*}$ Correspondence:

Sonia Berrih-Aknin

sonia.berrih-aknin@upmc.fr

Specialty section: This article was submitted to Thyroid Endocrinology,

a section of the journal

Frontiers in Endocrinology

Received: 04 May 2017 Accepted: 30 June 2017

Published: 13 July 2017

Citation:

Lopomo A and Berrih-Aknin S (2017)

Autoimmune Thyroiditis and

Myasthenia Gravis.

Front. Endocrinol. 8:169.

doi: 10.3389/fendo.2017.00169 mechanisms, such as deregulation of the immune system and the implication of the genetic predisposition. They also show some differences, such as the mode of action of the antibodies and therapies. In this review that focuses on ATD and MG, the common features and the differences between the two diseases are discussed.

Keywords: acetylcholine receptor antibodies, interferon type I, germinal centers, genetics, etiology

\section{INTRODUCTION}

Autoimmune diseases (AIDs) are the result of specific immune responses directed against structures of the self. Under normal conditions, the immune system is tolerant to molecules recognized as "self" and does not react to antigens expressed in endogenous tissues. If self-tolerance is missing, the immune system could develop an immune response against self-molecules, causing the development of AIDs that include autoimmune thyroid diseases (ATDs) and myasthenia gravis (MG).

The etiology of AIDs is multifactorial and involves genetic and environmental factors. ATDs are endocrine diseases due to an autoimmune reaction against thyroid antigens, in a specific genetic background triggered by exposure to environmental factors (1).

The two main ATDs are Graves disease (GD) and Hashimoto's thyroiditis (HT) that are characterized by hypothyroidism and thyrotoxicosis, respectively, by the production of thyroid autoantibodies such as thyroid peroxidase (TPO), thyroglobulin (TG), and thyroid-stimulating hormone receptor (TSHR), as well as by lymphocytic infiltration of the thyroid (1). MG is a neuromuscular disorder due to a defective transmission of the nerve impulse to muscles, causing muscle weakness and abnormal fatigability. In most cases, MG is mediated by antibodies targeting the acetylcholine receptor (AChR) while in a minority of patients, the autoantibodies are specific for muscle-specific kinase (MuSK) or agrin receptor LRP4 (low-density lipoprotein receptor-related protein-4). Other targets, such as titin, and ryanodine, have been investigated (2). 


\section{CONCOMITANT THYROIDITIS AND MG: EPIDEMIOLOGICAL FEATURES}

The prevalence of ATDs is high and estimated to be $5 \%$ in the general population (3) while MG is a rare disease with an incidence of 8-10 cases per one million persons/year and a prevalence of $150-250$ cases per one million (4) (Table 1). Although ATD is one of the most representative organ-specific autoimmune disorders, it is associated with other autoimmune endocrine failures or non-endocrine diseases (5). Among the non-endocrine diseases, we can mention vitiligo, pernicious anemia, MG, autoimmune gastritis, celiac disease, and hepatitis $(6,7)$. Interestingly, in these associated diseases, the presence of anti-TPO antibodies is more frequent than the prevalence of ATDs (6).

The aim of this review is to focus on the association between MG and ATDs. The most common diseases coexisting with MG are GD and HT, with a frequency of 7 and 3\%, respectively (13). ATDs were diagnosed in $26.8 \%$ of MG Polish patients including $4.4 \%$ with GD, $9 \%$ with $\mathrm{HT}$, and $13.4 \%$ with anti-thyroid antibodies (14). In British and German populations, $16 \%$ of early-onset MG (EOMG), $9 \%$ of late-onset MG, and 17\% of thymoma-MG patients had antibodies against TPO or TG (15). About $0.2 \%$ of patients affected by ATDs show MG that is much higher than the general incidence of MG (0.01\%). MG could be ocular or generalized, even if ATDs are more frequent in the ocular group (16-18). When associated to ATDs, MG shows specific features, such as the young age of onset, mild clinical symptoms, low levels of AChR antibodies, and low frequency of thymic alterations (18-20). These data highlight that the association between MG and ATDs is much more frequent than expected.

\section{ETIOLOGY}

The etiology of AIDs is still unknown. Drugs, virus infections, radiation, stress are some of the environmental factors that may be involved in the development of ATDs and MG in susceptible individuals, contributing to the activation of an innate immune response $(8,10,21,22)$.

\section{Factors of Predisposition}

Autoimmune thyroid diseases are more common among women than men with a female:male ratio of 5-10:1. There is a difference in prevalence and incidence in the base of geographic area, race, and age. The frequency of anti-thyroid antibodies increases with age, showing a peak ranging from 45 to 55 years. In females, one of the two X chromosomes is inactivated during early embryonic stage (23). The inactivation of the same $\mathrm{X}$ chromosome, that occurs in more than $80 \%$ of cells, could result in defect in immunological tolerance to X-linked antigens that could lead to autoimmunity. Moreover, fetal microchimerism was observed in blood and thyroid tissues from women with either HT or GD. During pregnancy, the production of maternal regulatory T cells (Treg) early in pregnancy could lead to a decrease in the circulating anti-thyroid antibodies, maintaining a state of tolerance to fetal alloantigens in order to avoid fetus rejection. After birth, anti-thyroid antibodies rebound with a transient increase. The persistence of fetal cells in maternal tissues leads to fetal microchimerism (24).

In MG, instead, the early-onset forms, characterized by the age of onset before 50 years, are more frequent in female than male with a ratio female:male of 3:1. Different studies suggest an important role of estrogens in MG (25), since estrogen receptors are expressed on thymic epithelial cells and on thymocytes (21). The female bias in AIDs could be due to reduced expression by estrogens of AIRE, a transcription factor involved in negative selection, resulting in a decreased quality of autoreactive cells elimination (26).

By case-control studies, and more recent genome-wide association studies, different genes have been associated with the ATDs and MG and the presence of specific autoantibodies. Genes involved in T-cell activation and regulation, such as protein tyrosine phosphatase non-receptor 22 (PTPN22), cytotoxic T-lymphocyte antigen-4 (CTLA4), and human leukocyte antigens (HLA), are associated with both ATDs and MG. PTPN22 is an intracellular protein tyrosine phosphatase bound to c-src tyrosine kinase, involved in T-cell activation (27); CTLA4 plays a role in inhibiting T-cell signaling, and the HLA is essential for presenting exogenous antigens for recognition by $\mathrm{CD} 4{ }^{+} \mathrm{T}$-helper cells (28). Other genes have been associated to a single disease, as indicated in Figure 1. Therefore, in both ATDs and MG, factors of predisposition include not only genetic background, but also the potential role of sexual hormones.

\section{Triggering Factors}

Hepatitis C virus (HCV) infection is the most associated to ATDs both in adults and children, in fact, infected HCV

TABLE 1 | Epidemiological and clinical features of patients with autoimmune thyroid diseases and myasthenia gravis (MG).

\begin{tabular}{|c|c|c|c|c|}
\hline & $\frac{\text { Hashimoto's thyroiditis }}{\text { Hypothyroidism }}$ & $\begin{array}{l}\text { Graves' disease } \\
\text { Hyperthyroidism }\end{array}$ & AChR-MG & MuSK-MG \\
\hline Incidence & About 2\% & About $2 \%$ & About $0.1 \%$ & About $0.01 \%$ \\
\hline $\begin{array}{l}\text { Female/male } \\
\text { ratio }\end{array}$ & Around 10 & Around 10 & $\begin{array}{l}\text { Early onset: } F>M(\text { ratio around } 3) \\
\text { Late onset: } F=M\end{array}$ & Around 6 \\
\hline $\begin{array}{l}\text { Tissue } \\
\text { pathology }\end{array}$ & $\begin{array}{l}\text { Damage of the thyroid } \\
\text { gland }\end{array}$ & Enlarged thyroid (diffuse goiter) & $\begin{array}{l}\text { Thymic pathologies, hyperplasia among the young patients, and } \\
\text { thymoma among the oldest patients }\end{array}$ & $\begin{array}{l}\text { No thymic } \\
\text { pathology }\end{array}$ \\
\hline
\end{tabular}

The data on this table were collected from the following Ref. (8-12). 


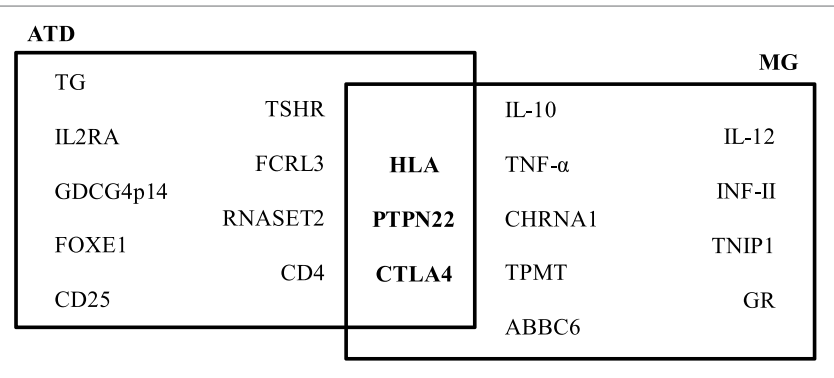

FIGURE 1 | Predisposing genes in autoimmune thyroid diseases (ATDs) and myasthenia gravis (MG). The data on this figure were collected from the following Ref. (28-30).

patients show dysfunctions in the thyroid $(10,31)$. In patients with chronic hepatitis $\mathrm{C}(\mathrm{CHC})$, the thyroid disorders are characterized by an increased risk of ATD and hypothyroidism in females, elevated levels of anti-TPO antibodies, and by papillary thyroid cancer risk $(32,33)$. The hypothesized mechanism is that $\mathrm{HCV}$ envelope protein E2 induces strong inflammatory responses in human thyrocytes, resulting in the production of interleukin (IL)-8, IL-6, and tumor necrosis factor- $\alpha$ (TNF- $\alpha$ ). The E2 protein also induces the upregulation of molecules involved in innate immune pathways (34). Also human herpes virus-6 (HHV-6) infection is associated with ATD onset, in fact, a high level of HHV-6 activation marker was found in thyroid tissue of patients with ATD (35). In myasthenic patients, the existence of a chronic inflammatory state in the thymus could alter innate immune responses leading to self-tolerance failure (36-39). The inflammatory state could be due to persistent viral replications, in fact, Epstein Barr virus (EBV), cytomegalovirus, human foamy virus, and Nile virus were found to be associated to MG $(40,41)$. Pathogen infections could play a role in AIDs through dysregulation of toll-like receptor-mediated innate immune responses, which can result in altered innate immune responses and long-term inflammation, rendering the thymus vulnerable to auto-sensitization $(40,41)$. EBV is one of the main candidates suspected to play a role in MG initiation, since it is able to promote B-cell abnormal activation and survival, and to disrupt critical B-cell tolerance checkpoints (40, 42-44).

Recent data have confirmed a strong association between ATD development and interferon (IFN)- $\alpha$ therapy in patients with $\mathrm{CHC}$. About $40 \%$ of $\mathrm{CHC}$ patients acquire thyroid disorders while receiving IFN- $\alpha$. IFN-induced thyroiditis is visible as clinical thyroiditis in about $15 \%$ of $\mathrm{HCV}$ patients receiving IFN- $\alpha$ and subclinical thyroiditis in up to $40 \%$ of patients (45). Moreover, it was observed that the generation of anti-thyroid antibodies tends to continue also after IFN therapy (30). IFN- $\alpha$ could induce thyroiditis by both direct toxic effects on the thyroid and by immune recruitment mechanisms (46).

Interestingly, IFN-I therapies can also prime the development of MG (47). IFN-I, especially IFN- $\beta$, could play a central role in the thymic follicular hyperplasia of MG patients by inducing high expression of $\alpha$-AChR and of CXCL13 chemokine in thymic epithelial cells, and of the chemokine CCL21 in endothelial lymphatic cells, two chemokines involved in the abnormal recruitment of B cells in EOMG thymuses. IFN- $\beta$ also increases $B$-cell activating factor expression, which promotes the development of autoreactive B cells (48). Also, IFN- $\beta$ overexpression in MG thymus can mediate the effects of dsRNA activation and causes $\alpha$-AChR subunit overexpression, suggesting that IFN- $\beta$ can play a central role in MG development (36).

Other drugs can induce AIDs, including immunomodulatory agents used to treat melanoma, such as monoclonal antibodies inhibiting the immune checkpoint pathways, as CTLA4 and programmed cell death protein 1 (PD-1), two-cell surface receptors on $\mathrm{T}$ cells which down-regulate immune response (49). Ipilimumab is a human immunostimulatory antibody targeting CTLA4 that can cause thyroiditis and/or hypothyroidism in 6\% of cases after several cycles. Pembrolizumab and nivolumab act against PD-1 and, if combined with ipilimumab to inhibit both CLT4 and PD-1, show a stronger effect with thyroiditis in $22 \%$ of cases (50).

\section{DIFFERENTIAL AND COMMON FEATURES IN ATDs AND MG}

\section{Antibodies}

Both MG and ATD diseases are organ specific and antibodymediated, and both kinds of disorders combine many different pathologies. Patients with ATDs have antibodies against proteins of the thyroid, but the characteristics of the disease differ according to the autoantigen. Patients with HT have serum antibodies reacting with TG, TPO, while patients with GD have antibodies against the receptor of TSH (51) (Table 2).

Myasthenia gravis is due to antibodies against the neuromuscular junction (59). Similarly to thyroiditis, in MG, several antigens are the targets of the autoantibodies, and the disease features depend upon the nature of the antibodies. Patients with anti-AChR, but not with anti-MuSK antibodies, have thymic pathologies, hyperplasia among the young patients, and thymoma among the oldest patients (60).

Interestingly, in both MG and ATDs, some forms of the disease are IgG4 dependent, an Ig subclass that does not bind to the complement. In MG, anti-MuSK antibodies are IgG4 (61). In ATDs, several subcategories of IgG4-mediated diseases have been identified including a fibrosing variant of $\mathrm{HT}$, IgG4-related HT, and GD with elevated IgG4 levels (62). These IgG4 diseases share common mechanisms that involve the mechanical interference of extracellular ligand-receptor interactions by the IgG4 antibodies (63).

The mechanisms of action of the antibodies are quite different in MG and ATD, likely due to the nature of the target antigen and its localization. In HT, together with cytotoxic cells, the antibodies contribute to the destruction of the thyroid, leading to hypothyroidism (Table 2). In the case of GD, the antibodies against TSHR could be stimulatory, blocking or neutral; when the stimulating antibodies predominate, clinical features become obvious (56). Thus, the antibodies are functional, able to stimulate or to inhibit the secretion of thyroid hormones. Fluctuating antibody levels can lead to syndromes alternating 
TABLE 2 | Physiopathological features of patients with autoimmune thyroid diseases and myasthenia gravis (MG).

\begin{tabular}{|c|c|c|c|c|c|}
\hline & & Hashimoto's thyroiditis & Graves' disease & AChR-MG & MuSK-MG \\
\hline \multirow[t]{3}{*}{$\begin{array}{l}\text { Humoral } \\
\text { immunity }\end{array}$} & $\begin{array}{l}\text { Target of the } \\
\text { autoantibodies }\end{array}$ & TG (20-50\%), TPO (90-95\%) & TSHR & AChR & MuSK \\
\hline & Mechanism of the Abies & $\begin{array}{l}\text { Thyroid destruction by cytotoxic cells, } \\
\text { death receptors, and impairment of } \\
\text { thyroid hormone production }\end{array}$ & $\begin{array}{l}\text { Overactivation of } \\
\text { the gland: thyroid } \\
\text { stimulatory, blocking, } \\
\text { and neutral Abies }\end{array}$ & $\begin{array}{l}\text { AChR blocking, internalization, } \\
\text { and degradation }\end{array}$ & $\begin{array}{l}\text { Disruption of } \\
\text { neuromuscular junction } \\
\text { and inhibition of the } \\
\text { retrograde signaling }\end{array}$ \\
\hline & Role of complement & Yes & Yes & Yes & No \\
\hline \multirow[t]{5}{*}{$\begin{array}{l}\text { Cellular } \\
\text { mechanisms }\end{array}$} & $\begin{array}{l}\text { Infiltration of the target } \\
\text { organ }\end{array}$ & +++ Thyroid & $\begin{array}{l}\text { + Thyroid, but not } \\
\text { destruction }\end{array}$ & $\begin{array}{l}\text { Neg in the muscle } \\
+++ \text { in the thymus }\end{array}$ & $\begin{array}{l}\text { Neg in the muscle } \\
\text { Neg in the thymus }\end{array}$ \\
\hline & Ectopic GC & Yes (thyroid) & Yes (thyroid) & Yes (thymus) & No \\
\hline & T-cell involvement & Th1, Th17 & Th2, Th17 & Th1, Th2, Th17 & Th1, Th17 \\
\hline & Role of epithelial cells & $\begin{array}{l}\text { Overproduction of pro-inflammatory } \\
\text { cytokines and chemokines by thyroid } \\
\text { epithelial cells }\end{array}$ & & $\begin{array}{l}\text { Overproduction of pro- } \\
\text { inflammatory cytokines and } \\
\text { chemokines by thymic epithelial } \\
\text { cells }\end{array}$ & Unknown \\
\hline & Regulatory B cells & Normal B10 number & Normal B10 number & Decreased B10 cell number & $\begin{array}{l}\text { Decreased B10 cell } \\
\text { number }\end{array}$ \\
\hline
\end{tabular}

The data on this table were collected from the following Ref. (1, 52-58).

between hyperthyroidism and hypothyroidism (64). In the case of MG, anti-AChR antibodies induce its degradation dependent upon the complement, and its internalization (2), while anti-MuSK antibodies disrupt the neuromuscular junction and inhibit the retrograde signaling $(65,66)$. Recent findings suggest that the anti-AChR antibodies could also have a functional effect, by inducing the overproduction of IL-6, a cytokine that plays a role in muscle biology (67). It is not clear yet if this mechanism participates to the pathogenic mechanisms or is a compensatory mechanism.

Most of the autoantibodies have a clinical usefulness. AntiTPO and anti-TSHR antibodies are relevant for the diagnosis of HT and GD, respectively $(30,68)$. Anti-TSH receptor antibodies are of interest in GD as they correlate with the disease severity and their levels decrease with therapies (69). However, anti-TPO and anti-TG Abs are not unique to HT patients since these antibodies are detectable in the majority of GD patients (70). In the case of MG, the anti-AChR antibodies are very useful for the diagnosis but not for the follow-up. On the other hand, for the group of patients with anti-MuSK antibodies, monitoring its level is relevant, since it correlates with the clinical course (2).

\section{Infiltration of the Target Organ and Germinal Centers}

Patients with GD can have an infiltration of the thyroid gland, while in the case of $\mathrm{HD}$, the infiltration is severe and accompanied by the destruction of the thyroid (71). Ectopic B-cell follicles are observed in the thyroid gland in HT (72). Autoreactive $\mathrm{B}$ cells within these lymphoid follicles were recognized by their ability to bind thyroid antigens (72). In MG, the neuromuscular junctions displays minimal lymphocytic infiltration, while the thymus at least in the young patients includes many infiltrating cells, signs of inflammation, and germinal centers (53). The degree of hyperplasia is related to the level of anti-AChR antibodies (73).

\section{Immune Dysregulation}

In both MG and ATDs, T-cell immune-mediated mechanisms are involved. In ATDs, cellular immunity targeting thyroid antigens is very common $(74,75)$. This mechanism is also a feature of experimental thyroiditis obtained in animals by injection of thyroid antigen with adjuvants (76). In MG, similar data are observed; in the patients, and in the experimental models of MG, T-cell proliferation using the autoantigen or peptides from the AChR has been shown (77-79).

In addition, inflammatory cells such as Th1 and Th17 were shown to be involved in the different forms of thyroid or myasthenic diseases (Table 2). Th1 cytokines are increased in MG patients and its experimental model (EAMG) and normalized with therapies $(80,81)$. Th1 cells and their cytokines are required for EAMG development (82), through the production of complement-dependent anti-AChR antibodies that are pathogenic $(82,83)$. In addition, TNF- $\alpha$ has been shown to contribute to the chronic inflammation observed in the MG thymus (84). In ATDs, Th1 cells recruited in the thyroid may be responsible for increased production of IFN- $\gamma$ and TNF- $\alpha$, which in turn stimulates the secretion of the pro-inflammatory chemokine CXCL10 from the thyroid cells, resulting in an amplification feedback loop, which could perpetuate the autoimmune process (1). Th17 cells and IL-17 have an inflammatory and pathogenic role in MG and ATD (85). Interestingly, IL-17 also contributes to B-cell responses. Indeed, mice mutated for IL-17 receptor have reduced humoral responses and germinal center development (86). In MG patients, the seric level of IL-17 is increased $(84,87)$. In the mouse model, IL-17 deficient mice are resistant to develop $\mathrm{MG}$, and the pathogenic anti-murine AChR antibodies are lower compared with wild-type mice (88). In ATDs, an increased differentiation of Th17 lymphocytes and an enhanced synthesis of Th17 cytokines were shown, mainly in HT (89).

Finally, the defects of immune regulation are a hallmark of AIDs. In both MG and thyroiditis, functional defects of Treg 
cells have been shown while the cell number is normal (90-92). In addition, there is a shift from Treg cells to Th17 cells, suggesting that Treg/Th17 balance is altered $(84,93)$. However, in MG, it was also demonstrated that the Teff cells are resistant to suppression (84). To our knowledge, there is no equivalent study in ATDs disorders. The number of B reg cells has been shown to be decreased in MG but not ATDs $(55,58,94)$.

Microbiota is essential for immunologic and digestive homeostasis (95) and is involved in many AIDs (52). In animals, the lack of microbiota is associated with reduced intestinal surface areas with shorter villi, changes in mucus layer, and permeability (5, 96), together with reduced B- and T-cell production (97). Interestingly, in humans, a morphological and functional damage of the intestinal barrier was similar in patients bearing type-1 diabetes and with ATD (98). In addition, in hyperthyroid patients, the microbiota composition was shown to be altered (99). This aspect has not yet been investigated in MG.

\section{THERAPIES}

Although both MG and ATDs are associated with immune system defects, the treatments are different. In the case of MG, treatments include anticholinesterase molecules and immunosuppressive therapies. Among these therapies are conventional immunosuppressant, such as azathioprine, as well as corticosteroids. Recently, monoclonal antibodies against B lymphocytes have proved interesting (100). In the case of thyroid disease, therapies are aimed at regulating thyroid hormone levels (101). The treatment of choice for HT or hypothyroidism is thyroid hormone replacement. The drug is orally administered usually for life.

Surgery is applied in both pathologies. In MG, thymectomy may be proposed when the thymus is hyperplastic or when a thymoma is associated. Recently, a Thymectomy Trial in NonThymomatous MG Patients Receiving Prednisone Therapy was conducted in order understand if transsternal thymectomy with prednisone therapy could be more efficient than prednisone

\section{REFERENCES}

1. Antonelli A, Ferrari SM, Corrado A, Di Domenicantonio A, Fallahi P. Autoimmune thyroid disorders. Autoimmun Rev (2015) 14:174-80. doi:10.1016/j.autrev.2014.10.016

2. Berrih-Aknin S, Frenkian-Cuvelier M, Eymard B. Diagnostic and clinical classification of autoimmune myasthenia gravis. J Autoimmun (2014) 4(8-49):143-8. doi:10.1016/j.jaut.2014.01.003

3. Hollowell JG, Staehling NW, Flanders WD, Hannon WH, Gunter EW, Spencer CA, et al. Serum TSH, T(4), and thyroid antibodies in the United States population (1988 to 1994): National Health and Nutrition Examination Survey (NHANES III). JClin Endocrinol Metab (2002) 87:489-99. doi:10.1210/jcem.87.2.8182

4. Gilhus NE. Myasthenia gravis. NEngl J Med (2016) 375:2570-81. doi:10.1056/ NEJMra1602678

5. Betterle C, Dal Pra C, Mantero F, Zanchetta R. Autoimmune adrenal insufficiency and autoimmune polyendocrine syndromes: autoantibodies, autoantigens, and their applicability in diagnosis and disease prediction. Endocr Rev (2002) 23:327-64. doi:10.1210/edrv.23.3.0466

6. Weetman AP. Diseases associated with thyroid autoimmunity: explanations for the expanding spectrum. Clin Endocrinol (Oxf) (2011) 74:411-8. doi:10.1111/j.1365-2265.2010.03855.x alone after 3 years. An improvement of clinical outcomes over a 3-year period in patients with non-thymomatous MG underwent thymectomy was observed (102). In ATDs, thyroid ablation is recommended in GD when the goiter is large, and in HT when a defined thyroid nodule is present (68). It is interesting to note that in both cases the organ that is operated is inflammatory and contains germinal centers with B lymphocytes participating in the pathogenic response.

\section{CONCLUSION}

In conclusion, MG and ATD share many commonalities. They are both organ-specific AIDs with a clear pathogenic effect of antibodies, although ATDs are 50-100 times more frequent than MG disease.

Interestingly, ocular involvement is observed in both pathologies. The pathological mechanisms high up many commonalities, such as deregulation of the immune system and the implication of predisposing genes, such as HLA and PTNP22 genes. However, the mode of action of the antibodies is different: if the antibodies in ATDs deregulate the level of the hormones, in the case of MG they reduce the expression of receptors at the motor plate leading to a functional defect of the synapse.

It is interesting to note that certain drugs are capable of inducing MG and ATDs, for example, IFN-I or monoclonal antibodies against immune checkpoints have proved to be inducers of these pathologies.

Finally, therapies in MG and ATDs are different. In ATDs, the use of molecules to regulate the level of the hormones is satisfactory. In MG, anticholinesterases are generally insufficient, and immunosuppressive therapy is very frequently associated.

\section{AUTHOR CONTRIBUTIONS}

$\mathrm{AL}$ and SB-A discussed the content of the review and wrote the manuscript.

7. Cellini M, Santaguida MG, Virili C, Capriello S, Brusca N, Gargano L, et al. Hashimoto's thyroiditis and autoimmune gastritis. Front Endocrinol (2017) 8:92. doi: $10.3389 /$ fendo. 2017.00092

8. Topliss DJ. Clinical update in aspects of the management of autoimmune thyroid diseases. Endocrinol Metab (Seoul) (2016) 31:493-9. doi:10.3803/ EnM.2016.31.4.493

9. DrachmanDB.Myastheniagravis.SeminNeurol(2016)36:419-24.doi:10.1055/ s-0036-1586265

10. Dong YH, Fu DG. Autoimmune thyroid disease: mechanism, genetics and current knowledge. Eur Rev Med Pharmacol Sci (2014) 18:3611-8.

11. Gilhus NE, Skeie GO, Romi F, Lazaridis K, Zisimopoulou P, Tzartos S. Myasthenia gravis-autoantibody characteristics and their implications for therapy. Nat Rev Neurol (2016) 12:259-68. doi:10.1038/nrneurol.2016.44

12. Jacobson DL, Gange SJ, Rose NR, Graham NM. Epidemiology and estimated population burden of selected autoimmune diseases in the United States. Clin Immunol Immunopathol (1997) 84:223-43. doi:10.1006/clin.1997.4412

13. Mao ZF, Yang LX, Mo XA, Qin C, Lai YR, He NY, et al. Frequency of autoimmune diseases in myasthenia gravis: a systematic review. Int J Neurosci (2011) 121:121-9. doi:10.3109/00207454.2010.539307

14. Kubiszewska J, Szyluk B, Szczudlik P, Bartoszewicz Z, Dutkiewicz M, Bielecki M,et al. Prevalence and impact of autoimmune thyroid disease on myasthenia gravis course. Brain Behav (2016) 6:e00537. doi:10.1002/brb3.537 
15. Klein R, Marx A, Ströbel P, Schalke B, Nix W, Willcox N. Autoimmune associations and autoantibody screening show focused recognition in patient subgroups with generalized myasthenia gravis. Hum Immunol (2013) 74:1184-93. doi:10.1016/j.humimm.2013.06.020

16. Tellez-Zenteno JF, Cardenas G, Estanol B, Garcia-Ramos G, Weder-Cisneros N. Associated conditions in myasthenia gravis: response to thymectomy. Eur J Neurol (2004) 11:767-73. doi:10.1111/j.1468-1331.2004.00968.x

17. Nakamura H, Usa T, Motomura M, Ichikawa T, Nakao K, Kawasaki E, et al. Prevalence of interrelated autoantibodies in thyroid diseases and autoimmune disorders. J Endocrinol Invest (2008) 31:861-5. doi:10.1007/BF03346432

18. Chen YL, Yeh JH, Chiu HC. Clinical features of myasthenia gravis patients with autoimmune thyroid disease in Taiwan. Acta Neurol Scand (2013) 127:170-4. doi:10.1111/j.1600-0404.2012.01693.x

19. Mistry N, Wass J, Turner MR. When to consider thyroid dysfunction in the neurology clinic. Pract Neurol (2009) 9:145-56. doi:10.1136/ jnnp.2008.167163

20. Nacu A, Andersen JB, Lisnic V, Owe JF, Gilhus NE. Complicating autoimmune diseases in myasthenia gravis: a review. Autoimmunity (2015) 48:362-8. doi:10.3109/08916934.2015.1030614

21. Kawashima A, Tanigawa K, Akama T, Yoshihara A, Ishii N, Suzuki K. Innate immune activation and thyroid autoimmunity. JClin Endocrinol Metab (2011) 96:3661-71. doi:10.1210/jc.2011-1568

22. Drutel A, Archambeaud F, Caron P. Selenium and the thyroid gland: more good news for clinicians. Clin Endocrinol (Oxf) (2013) 78:155-64. doi:10.1111/cen.12066

23. Brix TH, Knudsen GP, Kristiansen M, Kyvik KO, Orstavik KH, Hegedüs L. High frequency of skewed X-chromosome inactivation in females with autoimmune thyroid disease: a possible explanation for the female predisposition to thyroid autoimmunity. J Clin Endocrinol Metab (2005) 90:5949-53. doi:10.1210/jc.2005-1366

24. Lepez T, Vandewoestyne M, Hussain S, Van Nieuwerburgh F, Poppe K, Velkeniers B, et al. Fetal microchimeric cells in blood of women with an autoimmune thyroid disease. PLoS One (2011) 6:e29646. doi:10.1371/ journal.pone.0029646

25. Nancy P, Berrih-Aknin S. Differential estrogen receptor expression in autoimmune myasthenia gravis. Endocrinology (2005) 146:2345-53. doi:10.1210/ en.2004-1003

26. Dragin N, Bismuth J, Cizeron-Clairac G, Biferi MG, Berthault C, Serraf A, et al. Estrogen-mediated downregulation of AIRE influences sexual dimorphism in autoimmune diseases. J Clin Invest (2016) 126:1525-37. doi:10.1172/JCI81894

27. Lee YH, Rho YH, Choi SJ, Ji JD, Song GG, Nath SK, et al. The PTPN22 C1858T functional polymorphism and autoimmune diseases-a meta-analysis. Rheumatology (Oxford) (2007) 46:49-56. doi:10.1093/rheumatology/kel170

28. Simmonds MJ. GWAS in autoimmune thyroid disease: redefining our understanding of pathogenesis. Nat Rev Endocrinol (2013) 9:277-87. doi:10.1038/ nrendo. 2013.56

29. Avidan N, Le Panse R, Berrih-Aknin S, Miller A. Genetic basis of myasthenia gravis-a comprehensive review. J Autoimmun (2014) 52:146-53. doi:10.1016/j.jaut.2013.12.001

30. Tomer Y, Huber A. The etiology of autoimmune thyroid disease: a story of genes and environment. J Autoimmun (2009) 32:231-9. doi:10.1016/j. jaut.2009.02.007

31. Fallahi P, Ferrari SM, Giuggioli D, Manfredi A, Mancusi C, Fabiani S, et al. Thyroid involvement in hepatitis $\mathrm{C}$-associated mixed cryoglobulinemia. Hormones (Athens) (2014) 13:16-23.

32. Hammerstad SS, Jahnsen FL, Tauriainen S, Hyöty H, Paulsen T, Norheim I, et al. Inflammation and increased myxovirus resistance protein A expression in thyroid tissue in the early stages of Hashimoto's thyroiditis. Thyroid (2013) 23:334-41. doi:10.1089/thy.2012.0264

33. Fallahi P, Ferrari SM, Vita R, Benvenga S, Antonelli A. The role of human parvovirus B19 and hepatitis $\mathrm{C}$ virus in the development of thyroid disorders. Rev Endocr Metab Disord (2016) 17(4):529-35. doi:10.1007/s11154-016-9361-4

34. Hammerstad SS, Stefan M, Blackard J, Owen RP, Lee HJ, Concepcion E, et al. Hepatitis $\mathrm{C}$ virus E2 protein induces upregulation of IL-8 pathways and production of heat shock proteins in human thyroid cells. J Clin Endocrinol Metab (2017) 102:689-97. doi:10.1210/jc.2016-3403

35. Sultanova A, Cistjakovs M, Gravelsina S, Chapenko S, Roga S, Cunskis E, et al. Association of active human herpesvirus-6 (HHV-6) infection with autoimmune thyroid gland diseases. Clin Microbiol Infect (2017) 23:50. e51-e55. doi:10.1016/j.cmi.2016.09.023

36. Cufi P, Dragin N, Weiss JM, Martinez-Martinez P, De Baets MH, Roussin R, et al. Implication of double-stranded RNA signaling in the etiology of autoimmune myasthenia gravis. Ann Neurol (2013) 73:281-93. doi:10.1002/ ana. 23791

37. Cavalcante P, Le Panse R, Berrih-Aknin S, Maggi L, Antozzi C, Baggi F, et al. The thymus in myasthenia gravis: site of "innate autoimmunity"? Muscle Nerve (2011) 44:467-84. doi:10.1002/mus.22103

38. Cavalcante P, Cufi P, Mantegazza R, Berrih-Aknin S, Bernasconi P, Le Panse R. Etiology of myasthenia gravis: innate immunity signature in pathological thymus. Autoimmun Rev (2013) 12:863-74. doi:10.1016/j.autrev.2013.03.010

39. Cordiglieri C, Marolda R, Franzi S, Cappelletti C, Giardina C, Motta T, et al. Innate immunity in myasthenia gravis thymus: pathogenic effects of tolllike receptor 4 signaling on autoimmunity. J Autoimmun (2014) 52:74-89. doi:10.1016/j.jaut.2013.12.013

40. Cavalcante P, Galbardi B, Franzi S, Marcuzzo S, Barzago C, Bonanno S, et al. Increased expression of toll-like receptors 7 and 9 in myasthenia gravis thymus characterized by active Epstein-Barr virus infection. Immunobiology (2016) 221:516-27. doi:10.1016/j.imbio.2015.12.007

41. Barzago C, Lum J, Cavalcante P, Srinivasan KG, Faggiani E, Camera G, et al. A novel infection- and inflammation-associated molecular signature in peripheral blood of myasthenia gravis patients. Immunobiology (2016) 221:1227-36. doi:10.1016/j.imbio.2016.06.012

42. Bernasconi P, Barberis M, Baggi F, Passerini L, Cannone M, Arnoldi E, et al. Increased toll-like receptor 4 expression in thymus of myasthenic patients with thymitis and thymic involution. Am J Pathol (2005) 167:129-39. doi:10.1016/S0002-9440(10)62960-4

43. Le Panse R, Cizeron-Clairac G, Bismuth J, Berrih-Aknin S. Microarrays reveal distinct gene signatures in the thymus of seropositive and seronegative myasthenia gravis patients and the role of CC chemokine ligand 21 in thymic hyperplasia. J Immunol (2006) 177:7868-79. doi:10.4049/ jimmunol.177.11.7868

44. Cizeron-Clairac G, Le Panse R, Frenkian-Cuvelier M, Meraouna A, Truffault F, Bismuth J, et al. Thymus and Myasthenia gravis: what can we learn from DNA microarrays? J Neuroimmunol (2008) 20(1-202):57-63. doi:10.1016/j. jneuroim.2008.06.028

45. Hasham A, Zhang W, Lotay V, Haggerty S, Stefan M, Concepcion E, et al. Genetic analysis of interferon induced thyroiditis (IIT): evidence for a key role for MHC and apoptosis related genes and pathways. J Autoimmun (2013) 44:61-70. doi:10.1016/j.jaut.2013.04.002

46. Akeno N, Smith EP, Stefan M, Huber AK, Zhang W, Keddache M, et al. IFN-alpha mediates the development of autoimmunity both by direct tissue toxicity and through immune cell recruitment mechanisms. Jimmunol (2011) 186:4693-706. doi:10.4049/jimmunol.1002631

47. Dionisiotis J, Zoukos Y, Thomaides T. Development of myasthenia gravis in two patients with multiple sclerosis following interferon beta treatment. J Neurol Neurosurg Psychiatry (2004) 75:1079. doi:10.1136/jnnp.2003.028233

48. Cufi P, Dragin N, Ruhlmann N, Weiss JM, Fadel E, Serraf A, et al. Central role of interferon-beta in thymic events leading to myasthenia gravis. J Autoimmun (2014) 52:44-52. doi:10.1016/j.jaut.2013.12.016

49. Ribas A. Tumor immunotherapy directed at PD-1. N Engl J Med (2012) 366:2517-9. doi:10.1056/NEJMe1205943

50. Ryder M, Callahan M, Postow MA, Wolchok J, Fagin JA. Endocrine-related adverse events following ipilimumab in patients with advanced melanoma: a comprehensive retrospective review from a single institution. Endocr Relat Cancer (2014) 21:371-81. doi:10.1530/ERC-13-0499

51. Stassi G, De Maria R. Autoimmune thyroid disease: new models of cell death in autoimmunity. Nat Rev Immunol (2002) 2:195-204. doi:10.1038/nri750

52. Berrih-Aknin S. Myasthenia gravis: paradox versus paradigm in autoimmunity. J Autoimmun (2014) 52:1-28. doi:10.1016/j.jaut.2014.05.001

53. Berrih-Aknin S, Le Panse R. Myasthenia gravis: a comprehensive review of immune dysregulation and etiological mechanisms. J Autoimmun (2014) 52:90-100. doi:10.1016/j.jaut.2013.12.011

54. Berrih-Aknin S, Ragheb S, Le Panse R, Lisak RP. Ectopic germinal centers, BAFF and anti-B-cell therapy in myasthenia gravis. Autoimmun Rev (2013) 12:885-93. doi:10.1016/j.autrev.2013.03.011

55. Kristensen B. Regulatory B and T cell responses in patients with autoimmune thyroid disease and healthy controls. Dan Med J (2016) 63:B5177. 
56. Khan FA, Al-Jameil N, Khan MF, Al-Rashid M, Tabassum H. Thyroid dysfunction: an autoimmune aspect. Int JClin Exp Med (2015) 8: 6677-81.

57. Ajjan RA, Weetman AP. The pathogenesis of Hashimoto's thyroiditis: further developments in our understanding. Horm Metab Res (2015) 47:702-10. doi:10.1055/s-0035-1548832

58. Santaguida MG, Gatto I, Mangino G, Virili C, Stramazzo I, Fallahi P, et al. BREG cells in Hashimoto's thyroiditis isolated or associated to further organ-specific autoimmune diseases. Clin Immunol (2017). doi:10.1016/j. clim.2017.04.012

59. Le Panse R, Berrih-Aknin S. Autoimmune myasthenia gravis: autoantibody mechanisms and new developments on immune regulation. Curr Opin Neurol (2013) 26:569-76. doi:10.1097/WCO.0b013e328364d6cd

60. Berrih-Aknin S. Role of the thymus in autoimmune myasthenia gravis. Clin Exp Neuroimmunol (2016) 7:226-37. doi:10.1111/cen3.12319

61. Huijbers MG, Zhang W, Klooster R, Niks EH, Friese MB, Straasheijm KR, et al. MuSK IgG4 autoantibodies cause myasthenia gravis by inhibiting binding between MuSK and Lrp4. Proc Natl Acad Sci USA (2013) 110:20783-8. doi:10.1073/pnas.1313944110

62. Kottahachchi D, Topliss DJ. Immunoglobulin G4-related thyroid diseases. Eur Thyroid J (2016) 5:231-9. doi:10.1159/000452623

63. Huijbers MG, Querol LA, Niks EH, Plomp JJ, van der Maarel SM, Graus F, et al. The expanding field of IgG4-mediated neurological autoimmune disorders. Eur J Neurol (2015) 22:1151-61. doi:10.1111/ene.12758

64. Tamai H, Kasagi K, Takaichi Y, Takamatsu J, Komaki G, Matsubayashi S, et al. Development of spontaneous hypothyroidism in patients with Graves' disease treated with antithyroidal drugs: clinical, immunological, and histological findings in 26 patients. J Clin Endocrinol Metab (1989) 69:49-53. doi:10.1210/jcem-69-1-49

65. Cole RN, Reddel SW, Gervasio OL, Phillips WD. Anti-MuSK patient antibodies disrupt the mouse neuromuscular junction. Ann Neurol (2008) 63:782-9. doi:10.1002/ana.21371

66. Koneczny I, Cossins J, Vincent A. The role of muscle-specific tyrosine kinase (MuSK) and mystery of MuSK myasthenia gravis. J Anat (2014) 224:29-35. doi:10.1111/joa.12034

67. Maurer M, Bougoin S, Feferman T, Frenkian M, Bismuth J, Mouly V, et al. IL-6 and Akt are involved in muscular pathogenesis in myasthenia gravis. Acta Neuropathol Commun (2015) 3:1. doi:10.1186/s40478-014-0179-6

68. Caturegli P, De Remigis A, Rose NR. Hashimoto thyroiditis: clinical and diagnostic criteria. Autoimmun Rev (2014) 13:391-7. doi:10.1016/j. autrev.2014.01.007

69. Barbesino G, Tomer Y. Clinical review: clinical utility of TSH receptor antibodies. JClin Endocrinol Metab (2013) 98:2247-55. doi:10.1210/ jc.2012-4309

70. Menconi F, Marcocci C, Marino M. Diagnosis and classification of Graves' disease. Autoimmun Rev (2014) 13:398-402. doi:10.1016/j.autrev.2014.01.013

71. Wang SH, Baker JR. The role of apoptosis in thyroid autoimmunity. Thyroid (2007) 17:975-9. doi:10.1089/thy.2007.0208

72. Armengol MP, Juan M, Lucas-Martín A, Fernández-Figueras MT, Jaraquemada D, Gallart T, et al. Thyroid autoimmune disease: demonstration of thyroid antigen-specific $B$ cells and recombination-activating gene expression in chemokine-containing active intrathyroidal germinal centers. Am J Pathol (2001) 159:861-73. doi:10.1016/S0002-9440(10)61762-2

73. Truffault F, de Montpreville V, Eymard B, Sharshar T, Le Panse R, Berrih-Aknin S. Thymic germinal centers and corticosteroids in myasthenia gravis: an immunopathological study in 1035 cases and a critical review. Clin Rev Allergy Immunol (2017) 52:108-24. doi:10.1007/s12016-016-8558-3

74. Weetman AP. Determinants of autoimmune thyroid disease. Nat Immunol (2001) 2:769-70. doi:10.1038/ni0901-769

75. Dayan CM, Daniels GH. Chronic autoimmune thyroiditis. N Engl J Med (1996) 335:99-107. doi:10.1056/NEJM199607113350206

76. Flynn JC, Conaway DH, Cobbold S, Waldmann H, Kong YC. Depletion of L3T4+ and Lyt-2+ cells by rat monoclonal antibodies alters the development of adoptively transferred experimental autoimmune thyroiditis. Cell Immunol (1989) 122:377-90. doi:10.1016/0008-8749(89)90085-3

77. Sun JB, Harcourt G, Wang ZY, Hawke S, Olsson T, Fredrikson S, et al. T cell responses to human recombinant acetylcholine receptor-alpha subunit in myasthenia gravis and controls. Eur JImmunol (1992) 22:1553-9. doi:10.1002/eji.1830220631
78. Berrih-Aknin S, Cohen-Kaminsky S, Lepage V, Neumann D, Bach JF, Fuchs S. T-cell antigenic sites involved in myasthenia gravis: correlations with antibody titre and disease severity. JAutoimmun (1991) 4:137-53. doi:10.1016/0896-8411(91)90013-3

79. Fujii Y, Lindstrom J. Specificity of the T cell immune response to acetylcholine receptor in experimental autoimmune myasthenia gravis. Response to subunits and synthetic peptides. J Immunol (1988) 140:1830-7.

80. Conti-Fine BM, Milani M, Kaminski HJ. Myasthenia gravis: past, present, and future. J Clin Invest (2006) 116:2843-54. doi:10.1172/JCI29894

81. Im SH, Barchan D, Maiti PK, Raveh L, Souroujon MC, Fuchs S. Suppression of experimental myasthenia gravis, a B cell-mediated autoimmune disease, by blockade of IL-18. FASEB J (2001) 15:2140-8. doi:10.1096/ fj.01-0072com

82. Karachunski PI, Ostlie NS, Monfardini C, Conti-Fine BM. Absence of IFN-gamma or IL-12 has different effects on experimental myasthenia gravis in C57BL/6 mice. J Immunol (2000) 164:5236-44. doi:10.4049/ jimmunol.164.10.5236

83. Souroujon MC, Brenner T, Fuchs S. Development of novel therapies for MG: studies in animal models. Autoimmunity (2010) 43:446-60. doi:10.3109/08916930903518081

84. Gradolatto A, Nazzal D, Truffault F, Bismuth J, Fadel E, Foti M, et al. Both Treg cells and Tconv cells are defective in the myasthenia gravis thymus: roles of IL-17 and TNF-alpha. J Autoimmun (2014) 52:53-63. doi:10.1016/j. jaut.2013.12.015

85. Bedoya SK, Lam B, Lau K, Larkin J III. Th17 cells in immunity and autoimmunity. Clin Dev Immunol (2013) 2013:986789. doi:10.1155/2013/ 986789

86. Hsu HC, Yang P, Wang J, Wu Q, Myers R, Chen J, et al. Interleukin 17-producing $\mathrm{T}$ helper cells and interleukin 17 orchestrate autoreactive germinal center development in autoimmune BXD2 mice. Nat Immunol (2008) 9:166-75. doi:10.1038/ni1552

87. Roche JC, Capablo JL, Larrad L, Gervas-Arruga J, Ara JR, Sánchez A, et al. Increased serum interleukin-17 levels in patients with myasthenia gravis. Muscle Nerve (2011) 44:278-80. doi:10.1002/mus.22070

88. Schaffert H, Pelz A, Saxena A, Losen M, Meisel A, Thiel A, et al. IL-17producing $\mathrm{CD} 4(+) \mathrm{T}$ cells contribute to the loss of B-cell tolerance in experimental autoimmune myasthenia gravis. Eur J Immunol (2015) 45:1339-47. doi:10.1002/eji.201445064

89. Figueroa-Vega N, Alfonso-Pérez M, Benedicto I, Sánchez-Madrid F, González-Amaro R, Marazuela M. Increased circulating pro-inflammatory cytokines and Th17 lymphocytes in Hashimoto's thyroiditis. J Clin Endocrinol Metab (2010) 95:953-62. doi:10.1210/jc.2009-1719

90. Mao C, Wang S, Xiao Y, Xu J, Jiang Q, Jin M, et al. Impairment of regulatory capacity of $\mathrm{CD} 4+\mathrm{CD} 25+$ regulatory $\mathrm{T}$ cells mediated by dendritic cell polarization and hyperthyroidism in Graves' disease. JImmunol (2011) 186:4734-43. doi:10.4049/jimmunol.0904135

91. Glick AB, Wodzinski A, Fu P, Levine AD, Wald DN. Impairment of regulatory T-cell function in autoimmune thyroid disease. Thyroid (2013) 23:871-8. doi:10.1089/thy.2012.0514

92. Balandina A, Lecart S, Dartevelle P, Saoudi A, Berrih-Aknin S. Functional defect of regulatory CD4(+)CD25+ T cells in the thymus of patients with autoimmune myasthenia gravis. Blood (2005) 105:735-41. doi:10.1182/ blood-2003-11-3900

93. Li C, Yuan J, Zhu YF, Yang XJ, Wang Q, Xu J, et al. Imbalance of Th17/Treg in different subtypes of autoimmune thyroid diseases. Cell Physiol Biochem (2016) 40:245-52. doi:10.1159/000452541

94. Sun F, Ladha SS, Yang L, Liu Q, Shi SX, Su N, et al. Interleukin-10 producing-B cells and their association with responsiveness to rituximab in myasthenia gravis. Muscle Nerve (2014) 49:487-94. doi:10.1002/ mus. 23951

95. Shanahan F. The gut microbiota-a clinical perspective on lessons learned. Nat Rev Gastroenterol Hepatol (2012) 9:609-14. doi:10.1038/ nrgastro.2012.145

96. Natividad JM, Verdu EF. Modulation of intestinal barrier by intestinal microbiota: pathological and therapeutic implications. Pharmacol Res (2013) 69:42-51. doi:10.1016/j.phrs.2012.10.007

97. Macpherson AJ, Harris NL. Interactions between commensal intestinal bacteria and the immune system. Nat Rev Immunol (2004) 4:478-85. doi:10.1038/nri1373 
98. Virili C, Centanni M. Does microbiota composition affect thyroid homeostasis? Endocrine (2015) 49:583-7. doi:10.1007/s12020-014-0509-2

99. Zhou L, Li X, Ahmed A, Wu D, Liu L, Qiu J, et al. Gut microbe analysis between hyperthyroid and healthy individuals. Curr Microbiol (2014) 69:675-80. doi:10.1007/s00284-014-0640-6

100. Tandan R, Hehir MK II, Waheed W, Howard DB. Rituximab treatment of myasthenia gravis: a systematic review. Muscle Nerve (2017). doi:10.1002/ mus. 25597

101. Fallahi P, Ferrari SM, Elia G, Nasini F, Colaci M, Giuggioli D, et al. Novel therapies for thyroid autoimmune diseases. Expert Rev Clin Pharmacol (2016) 9:853-61. doi:10.1586/17512433.2016.1157468

102. Wolfe GI, Kaminski HJ, Aban IB, Minisman G, Kuo HC, Marx A, et al. Randomized trial of thymectomy in Myasthenia gravis. N Engl J Med (2016) 375:511-22. doi:10.1056/NEJMoa1602489
Conflict of Interest Statement: The authors declare that the research was conducted in the absence of any commercial or financial relationships that could be construed as a potential conflict of interest.

The reviewer, CR, and handling editor declared their shared affiliation, and the handling editor states that the process nevertheless met the standards of a fair and objective review.

Copyright (C) 2017 Lopomo and Berrih-Aknin. This is an open-access article distributed under the terms of the Creative Commons Attribution License (CC BY). The use, distribution or reproduction in other forums is permitted, provided the original author(s) or licensor are credited and that the original publication in this journal is cited, in accordance with accepted academic practice. No use, distribution or reproduction is permitted which does not comply with these terms. 